\title{
The Great Plume Debate
}

\section{Fort William, Scotland, August 28-September 1, 2005}

It is forty years since J. Tuzo Wilson first suggested that the Hawaiian Islands were produced by the oceanic lithosphere moving over a stationary "hotspot" in the mantle, and thirty years since W. Jason Morgan suggested that Wilson's hotspots are thermal plumes in the Earth's mantle, and that they may play an important role in convection. Flood basalts, volcanic continental margins, large oceanic plateaus and age-progressive aseismic ridges, along with smaller-volume seamount and ocean-island chains, have all been attributed to mantle plumes.

The tendency over the last decade has been to focus research on those features of large igneous provinces (LIPs) and hotspots that can be explained by plume theory and to ignore those features that cannot. Many papers published have treated the plume hypothesis as an a priori assumption. Recently, however, there has been significant critical thought on the subject and a global debate has developed on the validity of the plume hypothesis and on the viability of alternative models.

The fluid mechanics of low-Reynoldsnumber plumes is well understood. A mantle plume is predicted to consist of a large spherical head followed by a small tail. When it reaches the top of its ascent the head flattens to form a disk with a diameter twice that of the spherical head. Plume heads have been proposed to be responsible for Earth's major flood basalts and plume tails for aseismic ridges and island chains that connect the flood basalt to the current position of the hotspot. Plume theory makes the following testable predictions:

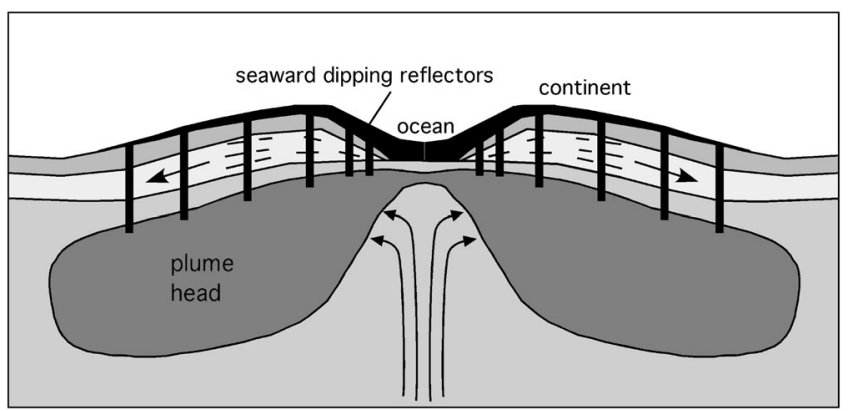

Phase 2 of the volcanism produced by the arrival of a new plume head. A 1,000 to 1,200 $\mathrm{km}$ diameter plume head rises beneath continental crust. As it reaches the top of its ascent it begins to flatten and melt, leading to the formation of a flood basalt (phase 1). Melting is due to adiabatic decompression and continues as long as the head continues to rise and flatten. Arrival of the plume head also leads to uplift, which places the lithosphere under tension, as shown by the arrows. The final diameter of the flatten plume head is 2,000 to 2,500 $\mathrm{km}$. Tension introduced by the plume head can lead to run-away extension and the formation of a new ocean basin. If this happen mantle from the hot plume head is drawn into the spreading centre leading to the formation of thickened oceanic crust (phase 2 volcanism). This second phase of volcanism may be more extensive than the first. The plume tail and structure of the head have been omitted to simplify the diagram and the vertical scale is exaggerated (after Campbell, 1998).

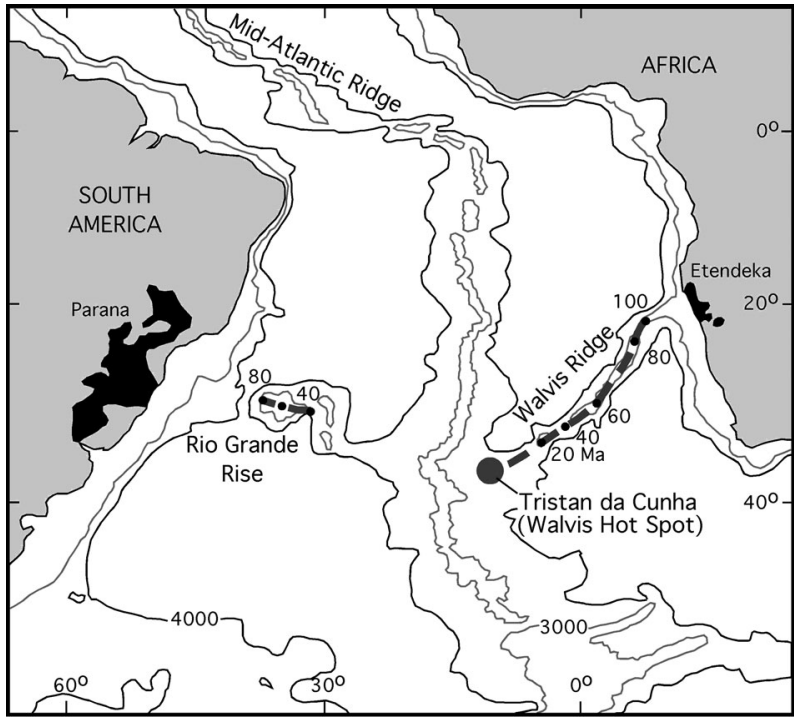

A map of the South Atlantic showing the position of the Parana and Etendeka flood basalts, Walvis Ridge, Rio Grande Rise and Tristan da Cunha, the current position of the plume. Between 120 and 60 Ma the Tristan da Cunha plume underlay the MidAtlantic Ridge and produced two aseismic ridges, the Walvis Ridge on the east side of the spreading cetntre and the Rio Grande Rise on the west side (after White and McKenzie, 1989)

held on each of the disciplines that can contribute to the debate. Sessions were held on: anism, the temperature of magma sources,

As the debate progressed it became clear that all of the phenomena predicted by the plume hypothesis have been observed in large igneous provinces. There is evidence for (i) flatten plume head being up to 2,500 km across in upper manle, (ii) flood volcanism being proceeded by perature magmas and (iv) eismic evidence that plumes extend to the coremantle boundary. The excellent agreement between theory and observations has convinced most Earth scientists that plume theory is soundly based.

The sceptics argued that there are many observations that are not predicted by the classical plume model. These include observations that suggest that "hotspots" may not be hot, that age progressions are often complicated and not linear, and that the deepmantle structures expected beneath large volcanic provinces are not observed. Enigmatic co-locations of hotspots with unusual surface tectonic features are viewed by many as being unlikely to be mere coincidences. Alternative models for "hotspots" that were proposed included shallow magmatic, and propagating crack models, local convection and recycling of subducted slabs, Rayleigh-Taylor instability of the lithosphere for continental flood basalts, impacts, variations in stress at the junction of tectonic features and EDGE-driven convection. It has been suggested that much of the hotspot volcanism that has traditionally been attributed to deep mantle plumes is, instead, controlled by shallow processes driven ultimately by plate tectonics. However the sceptics failed to come up with a single observation that seriously challenged the plume hypothesis or to present a viable alternative hypothesis to explain flood basalts and their associated age-progressive aseismic ridges. In particular they failed to offer an explanation for the high-temperature picrites, which are commonly associated with flood basalts, or the high eruption rates of flood volcanism and their short duration.

Pre- syn- and post-conference field trips were held to Ballachulish, Glen Coe, Arisaig and to the islands of Rum, Mull and Skye. The Great Plume Debate was sponsored by the American Geophysical Union and the IUGS Commission for Solid Earth Chemistry and Evolution (SECE).

Conveners: Ian Campbell, Godfrey Fitton, Gillian Foulger, Dean Presnall and Jason Morgan.

\section{Dr. Ian H. Campbell}

Senior Fellow

Research School of Earth Sciences

The Australian National University

Canberra, ACT 0200

AUSTRALIA

Ian.Campbell@anu.edu.au

Also Secretary General of IUGS Commission on Solid earth Composition and Evolution (http://www.dur.ac.uk/secel) 


\title{
Joint IGCP 499/SDS Meeting
}

\author{
Siberia, Russia, July 25-August 9, 2005
}

A major event of IGCP 499 in 2005 took place in Southern Siberia. In the tradition of successful joint meetings and field trips of Devonian IGCP projects and the international Subcommission on Devonian Stratigraphy (SDS), a very successful meeting was held at the Institute of Petroleum Geology, United Institute of Geology and Mineralogy of the Russian Academy of Sciences, Siberian Branch in Novosibirsk. The meeting, which included a splendid field trip to the South of Siberia (July 26-August 6, 2005) and well-organised technical sessions (August 7-8, 2005), was run by a great group from Novosibirsk under the guidance of $\mathrm{E}$. A. Yolkin, A. V. Kanygin, N. K. Bakharev, N. G. Izokh, and O. T. Obut (and a wonderful team helping to arrange the sessions and the field trip in a perfect way!).

The meeting was entitled "Devonian Terrestrial and Marine Environments: From Continent to Shelf" (DECONS). About 75 scientists (among them 32 colleagues from various foreign countries) presented 35 oral lectures and 44 posters dealing with topics that spanned the entire Devonian and different aspects such as stratigraphy, sedimentology/facies, palaeontology, palaeoecology, palaeogeography, events, isotopes, regional geology and correlations of all kinds of rocks generated under different environmental settings (pelagic to terrestrial). The organisers provided simultaneous translation, from Russian to English and vice versa, during all the technical sessions as well as the closing ceremony and farewell reception. During the field trips, Olga Obut acted as translator at the numerous stops and other affairs on the route. Business meetings of IGCP 499 and

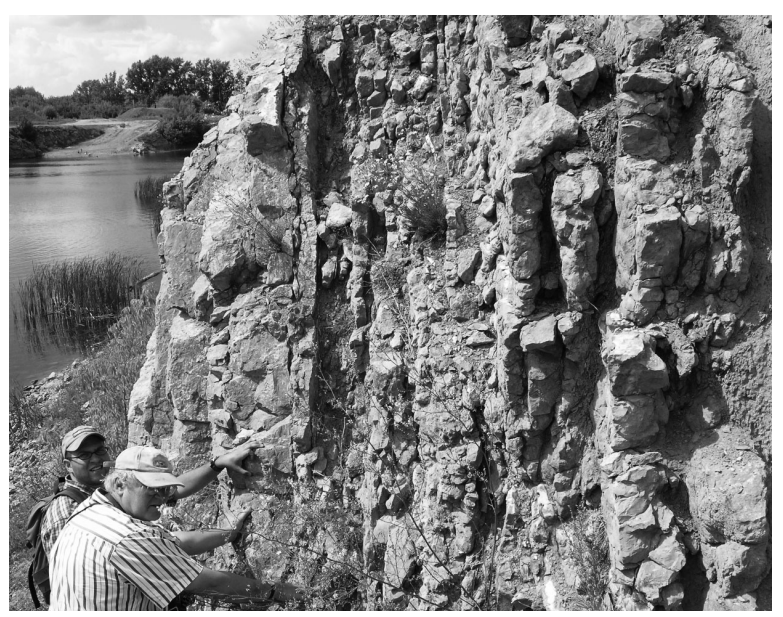

Figure 1 Carl Brett and Alex Bartholomew examine Lower Devonian (Lochkovian) rocks in the Old Gur'evsk Quarry (Salair area, vicinity of the town of Gur'evsk). Photo: E. Schindler.
SDS were held on August $8,2005$.

The field trip led the participants to various Devonian outcrops in the Salair, Rudny Altai, and Gorny Altai regions, yielding a great variety of rocks in different facies settings from nearshore/ terrestrial to open marine conditions and from the Lower to the Upper Devonian. Four field camps were set up by the perfectly working team. Vivid discussions arose when especially the non-Russian participants studied the successions which often comprised very unusual facies compared with thier own experiences, e.g., substantial parts of the Lower Devonian in calcareous facies, marine/terrestrial transitions - or even terrestrial strata-at levels new to many participants, etc.

In the Salair area (in the vicinity of the town of Gur'evsk) the first field camp was actually situated in (!) one of the stops of the field trip which was not only charming by having a wonderful lake, but also yielding splendid outcrops (Tolstochikha Quarry). For many participants-especially those from foreign countries - the development of the Lochkovian in limestone facies was quite unusual compared to many other regions of the world. A similar setting of Lochkovian rocks was present in the Old Gur'evsk Quarry (Figure 1). Younger strata of the Lower Devonian could be investigated at a railway cutting in the vicinity of Gur'evsknamely the very fossiliferous Emsian Salairka Horizon. In the giant active Akarachkino Quarry Emsian Shanda Beds (Figure 2) and a coal seam of Eifelian age could be studied.

In the Rudny Altai area mainly younger rocks could be studied, reaching into the Famennian. One of the sections close to the second field camp at the banks of the Gryaznukha Brook showed an impressive succession of Frasnian rocks, including strata deposited in deeper water (e.g., with radiolarians, goniatites) as well as allochthonous blocks of carbonate rocks.

In the Gorny Altai area sequences of Lower to Upper Devonian rocks were studied in
Figure 2 In the Akarachkino Quarry the Emsian 'Middle Shanda Beds' clearly show a pattern of cyclic sedimentation the impressive landscape of this mountainous region.

It was planned to publish results of the conference in a special volume of the journal Courier Forschungsinstitut Senckenberg.

Additional information can be obtained from the website of IGCP Project 499 http://www.senckenberg.de/igcp-499 and related links.

\section{Literature}

Yolkin, E.A., Bakharev, N.K., Izokh, N.G., Gratsianova, R.T., Kipriyanova, T.P. and Obut, O.T., 2005, Devonian terrestrial and marine environments: From continent to shelf, Joint Conference IGCP 499/SDS, Devonian sequences of Salair, Rudny \& Gorny Altai: Field excursion guidebook, Novosibirsk, 82 pp.

Yolkin, E.A., Izokh, N.G., Obut, O.T., and Kiprianova, T.P., eds., Devonian terrestrial and marine environments: From continent to shelf, Joint Conference IGCP 499/SDS, Contributions, Novosibirsk, 156 pp.

Dr. Peter Königshof, Dr. Eberhard Schindler, Dr. Volker Wilde

Forschungsinstitut und Naturmuseum Senckenberg, Senckenberganlage 25, D-60325 Frankfurt am Main GERMANY

Peter.Koenigshof@senckenberg.de Eberhard.Schindler@senckenberg.de Volker.Wide@senckenberg.de

\section{Dr. Jurga Lazauskiene}

Geological Survey of Lithuania,

Department of Lithostratigraphy and Tectonics Konaskio 35, LT-2009 Vilnius LITHUANIA

Jurga.Lazauskiene@lgt.li

\section{Prof. Dr. M. Namik Yalçin}

Istanbul University, Engineering Faculty, Department of Geological Engineering, TR-34850 Avcilar-Istanbul TURKEY

mny@istanbul.edu.tr 


\section{IGCP-499 Workshop "Depositional Environments of the Gondwanan and Laurasian Devonian"}

\author{
Istanbul, Turkey, September 26-October 3, 2005
}

Turkey is a region of special interest for Devonian researchers because it comprises Laurasian and Gondwanan components situated on different but neighbouring tectonic blocks. The respective strata include a variety of facies representing different shelf to marginal marine and even continental environments.

For this reason, a group of active Devonian researchers was assembled in Turkey by co-leader M.N. Yalcin to focus on the goals of IGCP-499. The highly successful meeting was held in the historic main building of Istanbul University, situated in the heart of the historic city and overlooking the unique panorama of the Golden Horn. It was attended by about fifty colleagues, mainly from Turkey, but also from Bulgaria, Germany, Lithuania, Morocco, and the USA. About twenty oral contributions and several posters covered major aspects of the subject with a special focus on the Devonian of Turkey and adjacent areas. There was sufficient time to initiate stimulating discussions between individual researchers and different working groups. Because all of the five co-leaders of IGCP-499 joined the meeting, an extended business meeting of the project was held during the period of the workshop.

Two fieldtrips were offered in conjunction with the meeting and enabled participants to see both the Laurasian and the Gondwanan components of the Turkish Devonian. On September 28, a large number of the participants visited outcrops cov-

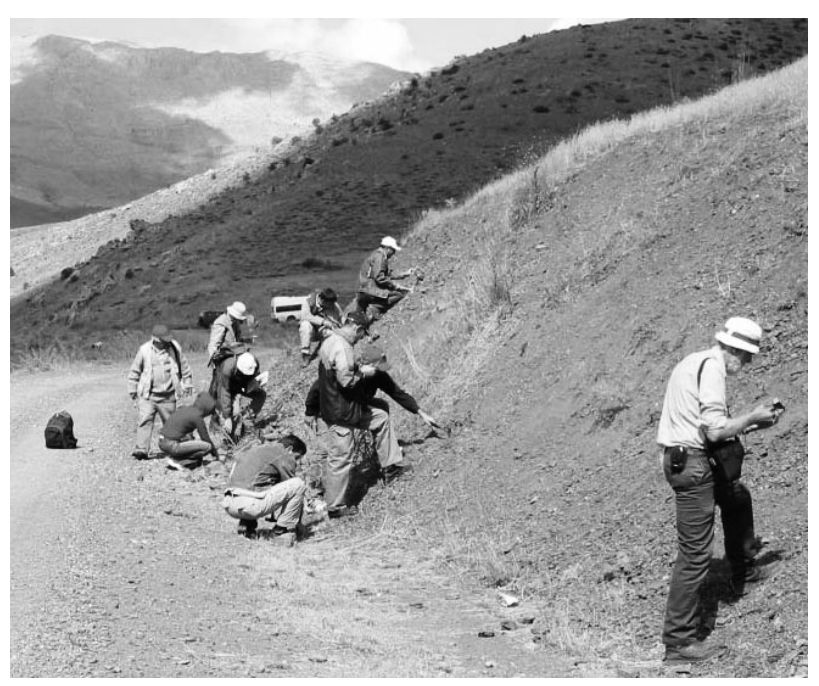

Fieldwork in the Eastern Taurides ering an almost complete and representative fossiliferous section of Ordovician to Lower Carboniferous sedimentary rocks of Laurasian affinity in the eastern and northeastern environs of Istanbul. The second fieldtrip was devoted to two major sections of Gondwanan affinity in the Eastern Taurus Mountains of Southern Turkey ( September 30-October 3 ). It was attended by only a few overseas participants but made possible intensive cooperative fieldwork on the respective sections by Turkish and German colleagues. Following travel to Kayseri as the starting point, there was some sightseeing in the famous historic centre of the town. The next two days were devoted to the Değirmentas Section between Değirmentas and Halevik villages in the NNE of the Tufanbeyli District. The more or less continuous section starts with Cambrian sedimentary rocks including major carbonates and ends in the Carboniferous, in between covering an almost complete Devonian section, which was studied in some detail. The next day enabled participants to experience some historic places of great importance north of Adana. The subject of the last two days of the fieldtrip was the Civiklı Section which covers most of the Devonian, including the Devonian/ Carboniferous Boundary. The official part of the fieldtrip was followed by more extended fieldwork in the framework of a bilateral Turkish-German cooperation project (DEVEC-TR).

The workshop and accompanying fieldtrips can be regarded as highly successful. They offered a unique opportunity to get an insight into the Devonian of Turkey which covers two major palaeogeographic "complexes" in close proximity. The Turkish colleagues must be thanked for organizing and hosting a splendid workshop. They not only offered a fascinating insight into Devonian stratigraphy, but also the wonderful Turkish landscape, culture, and hospitality. Participants were provided with a nice booklet specially published for the meeting, which comprised not only the abstracts but also an introduction to the Devonian of Turkey and details of the areas covered by the fieldtrips.

Further information can be obtained from the IGCP 499 website (http://www.senckenberg.de/igcp-499) and related links.

\section{Dr. Peter Königshof, Dr. Eberhard Schindler and Dr. Volker Wilde} Forschungsinstitut und Naturmuseum Senckenberg, Senckenberganlage 25, D60325 Frankfurt am Main GERMANY

Peter.Koenigshof@senckenberg.de Eberhard.Schindler@senckenberg.de Volker.Wilde@senckenberg.de

\section{Dr. Jurga Lazauskiene}

Geological Survey of Lithuania, Department of Lithostratigraphy and Tectonics

Konaskio 35, LT-2009 Vilnius

LITHUANIA

Jurga.Lazauskiene@lgt.li

Prof. Dr. M. Namik Yalçin Istanbul University, Engineering Faculty Department of Geological Engineering TR-34850 Avcilar-Istanbul

TURKEY

mny@istanbul.edu.tr 


\section{Geoenvironmental problems and cross- border cooperation in Central America}

\author{
Managua, Nicaragua, December 5-8, 2005
}

The International Workshop on "Geoenvironmental problems and cross-border cooperation in Central America" was organized in Managua, Nicaragua, 5-8 December, 2005 by the Working Group International Borders - Geoenvironmental Concerns (IBC), under the IUGS Commission on Geosciences for Environmental Management (GEM) and in the framework of the IUGS funded project "Application of geosciences for sustainable development of cross-border areas (GEOCrossBorder)".

The Workshop in Managua aimed to evaluate the state of cross-border cooperation in Central American countries, and to initiate active discussions on the practical application of geosciences in cross-border areas of that region. The Workshop comprised 13 oral presentations ( 7 by invited lectors, and 8 by scientists from Central America) that addressed the prevention and mitigation of natural and anthropogenic-induced hazards. One of the main topics of the Workshop was trans-boundary (international) coordination aimed at ensuring the interaction and integration of different ongoing geoscientific and disaster prevention projects in Central America.

The major geoenvironmental issues of cross-border areas in Central America involve both scientific and regulatory aspects of geoenvironmental problems, such as seismicity, volcanism, exploitation of geothermal energy, landslides, water-shed management, and mitigation of geohazards. These issues were emphasized during the Managua Workshop.

The Workshop had sessions for presented papers and a field trip. Sessions were programmed over the first two days and were held at the Nicaraguan Geosciences Institute (INETER). These were followed by a twoday field trip, conducted by Dr. Jiri Sebesta (Czech Geological Survey), into the surroundings of the capital city Managua, and the northwest area of the Nicaragua volcanic chain. The field trip focused on studies of tectonics and volcanism (especially volcanic and earthquake hazards), and exogenic hazards, in the Managua region. The last activity of the Workshop was a visit to INETER, that involved meetings with top managers and specialists of that institution, and also the summarising of the results of the Workshop at a closing session.

The 32 participants from Nicaragua, Costa Rica, Panama, El Salvador, Honduras, Germany, Czech Republic, Lithuania, and Poland attended the Workshop. Wilfried Strauch, Director General of the Geophysical
Department of INETER, and Jonas Satkunas on behalf of IUGS, opened the Workshop with welcoming addresses. This was followed by the keynote presentations:

- Geology, environment and international borders. Jonas Satkunas, \& Marek Graniczny.

- Cross-border cooperation in the field of geology and geoenvironment-experience from the Baltic Region. Jurga Lazauskiene, \& Jonas Satkunas

- Geohazards mapping in Nicaragua and El Salvador. Jiri Sebesta

- Remote sensing - interferometric methods in cross border studies. Marek Graniczny.

The presentations that followed were given by representatives of different Central American countries and addressed to the most urgent geoenvironmental problems of the region.

More efficient cross-border cooperation is a major need, especially in relation to the rapidly increasing use of geothermal energy in the very seismically-active regions. Several ongoing geothermal projects in El Salvador, Nicaragua, and Costa Rica, are mostly concentrated in the volcanically-active surroundings of the Ausoles, Momotombo, and Miravalles volcanoes, respectively. In all these cases, the volcanic calderas are usually dissected by different fault systems and the exploitation of the geothermal energy might affect existing stress and strain condition of the geothermal reservoirs. Thus intensive exploitation of geothermal energy could stimulate an increase in seismicity, not only in the adjacent surrounding of the geothermal fields, but also in wider cross-border areas as well. For instance, monitoring of the Miravalles geothermal field in Costa Rica has been carried out by Instituto Costarricense de Electricidad (ICE) for more than 15 years. Geothermal exploitation commenced there in 1994 and seismicity started to increase in 2000 resulting in more than 100 micro-earthquakes $\left(\mathrm{M}_{\mathrm{L}} \leq 3,4\right)$ being recorded in a 10 month period. Simultaneous trends of an increase in magnitude, and the depth range of earthquakes, has also been recorded. The relatively small area $\left(5 \mathrm{~km}^{2}\right)$ of the exploited geothermal field has subsided $5 \mathrm{~cm}$ during the period from 1999 to 2003. This is regarded as a normal phenomenon most probably related to the tectonic structure of the volcanic caldera.

Apart from the above-mentioned project, ICE has two other geothermal projects involving two geothermal power plants that are under construction close to Rincón de la Vieja Volcano. Thus it is of great importance to understand the mechanisms and relationships between the geothermal and seismic phenomena, to evaluate the probability that the use of geothermal energy might induce an increase in seismicity, and to determine its scale. According to predictions the probable relationship between earthquakes and local faults might have a maximal magnitude $\left(\mathrm{M}_{\mathrm{L}}\right)$ of $\leq 5.0$, and these might affect the stability of some small villages surrounding the geothermal fields.

Other important geoenvironmental problems of the Central American region that were mentioned included:

- The watershed of the Rio Lempa that is shared by Guatemala, Honduras, and El Salvador. Currently there are no signed agreements between these countries to address joint environmental management.

- The need for joint cross-border evaluation and monitoring of volcanic risk-as exemplified by the El Chico Volcano

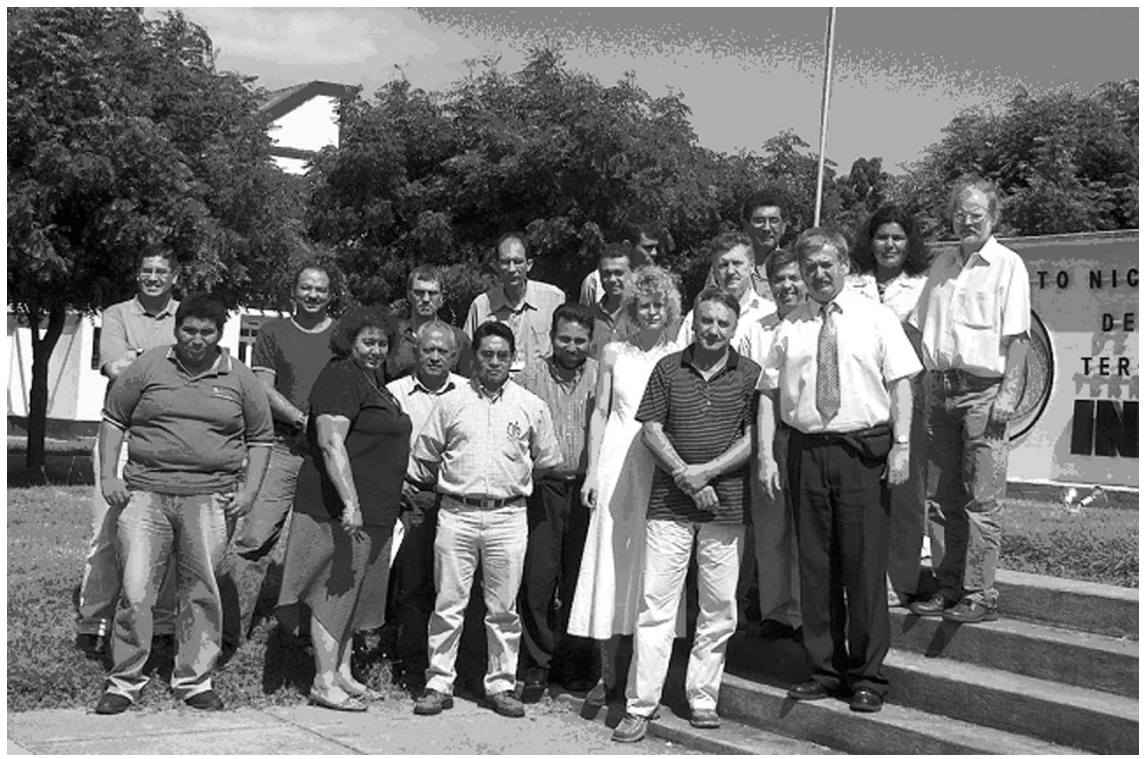

The participants and organizers of the Workshop. 


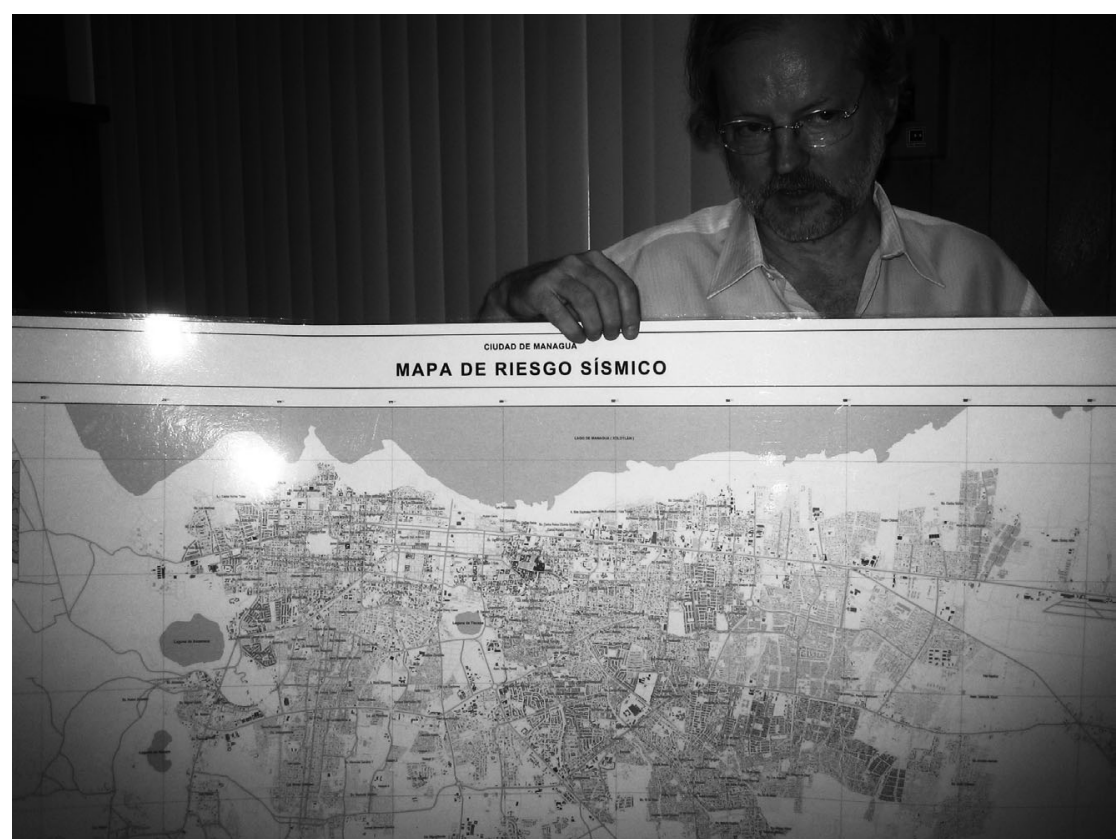

Wilfried Strauch, Director General of the Geophysical Department of INETER demonstrates the Managua City Seismic Risk Map.

located in the Honduras-Guatemala crossborder area.

- Landslides are one of the most important geohazards in the Panama-Colombia cross-border area. The complicated subduction zone setting of the area involves active tectonics with significant seismicity that can trigger landslides.

- High-voltage electricity power lines (transmitting 220000 watts) transect the area from Costa Rica and Nicaragua through other Central America countries. Due to the mountainous relief many electricity poles are located on the slopes or tops of hills and mountains which have an increased risk of landslide occurrences. Thus there is a need to carry out an inventory of all the sites with increased vulnerability for landslides or other geohazards occurrences.

The two-day field trip allowed the Workshop attendees to get acquainted with local geoenvironmental phenomena in their natural conditions. The first day of the excursion travelled into the northwestern part of the famous Nicaraguan volcanic chain. The San Cristóbal volcanic group comprises the highest part of the Cordillera de los Marabios massive that is approximately $70 \mathrm{~km}$ long with the volcanic group forming its northern closure. The line of volcanos lies some 25 $\mathrm{km}$ from the Pacific coast. The foothills of volcanic chain has an altitude of about 150-200 $\mathrm{m}$ on the southern and northern sides, and the northern margin of the volcanoes lies in the subsidence zone of the Nicaragua Depression. The San Cristóbal volcanic group includes two major stratovolcanoes formed in La Pelona caldera, a number of minor volcanoes (El Chonco, Moyatape, Acastepe), as well as volcanic centers of various origin. The San Cristóbal volcanic group extends along the southwestern mar- gin of the Nicaragua Depression. The highest volcano of the group-San Cristóbal volcano (1754 m a.s.1.) - forms a typical cone-shaped stratovolcano that is still active. Its structural slopes, formed by lava flows and very loose and unstable pyroclastic fallout material, are still being formed. Casita, another major volcano, does not show activity at the moment, nevertheless, an intensive hydrothermal alteration of lava flows and agglomerates forming the volcano slopes bears witness to its activity in the past. The surface of the volcano is covered with up to several tens of meters of thick polygenetic (and rather unstable) slope deposits, layered on the clayey weathered background. The volcanoes of the San Cristóbal volcanic group have formed from the Plio-Pleistocene up to the present. The development of the volcanic group is closely related to the formation of the Nicaragua Depression which has been forming since the Upper Miocene. The major volcanoes are formed on the junction of several fault systems (Nicaragua Depression, Laguna Verde fault and other NE-, NW- and NS-trending fault systems), while the major volcanic centers are located along the margin of the Nicaragua Depression.

The region visited by the excursion has different degrees of exposure to high geological risks of exogenic and endogenic origin. Extreme rainfall that causes a number of exogenic processes with a degree of risk, is one of the important exogenic phenomena. The most recent case was the devastation by hurricane Mitch in October 1998, which caused a catastrophic flash flood that annihilated two villages. The area is affected not only by exodynamic but also volcanic and seismic risks. The region is a potential focus of volcanic activity, though a number of volcanic centers lack any historical data. The formation of entirely new, small volcanic centers (slag cones) that might produce slags, ashes or lava flows also must be considered and evaluated. In August 1999 three volcanic centers suddenly formed close to the foot of the Cerro Negro volcano and were active for a week. Field trip participants were able to climb to the top of the Cerro Negro; that was a great scientific experience.

The second day of the field trip visited the Masaya volcano with its calderas, and Apoyo caldera, to study the tectonic and volcanic processes surrounding the capital city of Managua. The topographic relief of the area around Managua is of volcano-tectonic origin and geologically very young-from Plio-Pleistocene age to recent. The exogenic processes involved in formation of the topographic relief had a cyclical character during the time span between the volcanic and tectonic phases. The area visited is located within the volcanically and tectonically very active zone at the southwest margin of the Nicaragua Depression. The Masaya volcanic system and calderas comprises the largest and the most important zone for seismic risk. This involves the Managua Graben structural zone and its margins, the Cofradia fault, Aeropuerto fault and the Nejapa-Miraflores lineaments. Though the Managua Graben appears to be geologically old, it is still subject to tectonic and volcanic development. At least four stages of structural development formed this pull-apart structure: tectonic subsidence, magma intrusion, discharge of magma chambers, and caldera formation.

Most of the area comprises chaotically arranged tectonic blocks that are locally covered by thick younger volcanic accumulations that formed in the depressional part of a cuesta system. The volcano-tectonic and the exogenic evolution of the area is characterised by a pattern of polycyclic deposition. The whole area is considered as a region with high geological vulnerability, prone to seismic and volcanic risks, and to a lesser degree exogenic risks.

On the last day of the Workshop the group visited the Nicaraguan Geosciences Institute (INETER) and gained acquaintance with its organizational structure, the range of its activities, and its achievements. INETER undertakes a wide range of activities, some of them covering the tasks of a geological survey. The institution:

- maintains, improves and operates the networks of seismic, accelographic and geophysical stations, and maintains volcanic surveillance. It acquires, accumulates, organizes, systematizes and stores basic data and prepares data for early warning systems;

- carries out scientific research aimed at characterizing geological hazards, supplies the data and knowledge to the Civil Defense and the National Emergency Commission, to ensure the efficient planning of prevention and mitigation measures;

- provides technical recommendations on the planning and establishment of human 
settlements, economic investments, and general land-use planning;

- initiates and carries out seismic, volcanic, tsunami and landslide monitoring. It acquires and distributes the official information and alert messages to inform the society about the occurrence and development of any dangerous geological, seismic and volcanic phenomena.

In conclusion, it should be emphasized that there are few geonvironmental studies, particularly in cross-border areas, in Central America. Practically no monitoring projects are ongoing in cross-border areas with the exception of regional scale seismological monitoring which is carried out by: the Nicaraguan Geosciences Institute (INETER), the Central America Seismic Centre (CASK), the University of Costa Rica (UCR) Seismic Network, the National Seismic Network (Panama), and the Colombian Seismic Network (INGEOMINAS).

Costa Rica has a cooperation agreement involving geology and seismicity activities between the Instituto Costarricense de Electricidad (ICE), the Nicaraguan Geosciences Institute (INETER), the University of Costa Rica (UCR), and the Universidad Nacional AutÛnoma de Nicaragua (UNAN).

Geological studies in Honduras are also very few. Only 20 geological maps, and one geotectonic map at the scale of 1:50 000, exist in the whole country. Some enterprises, such as national and international mining companies, obtain and store some geoscientific information but with limited public access to the data.
In El Salvador there is an urgent need of basic geological and hydrological maps at a scale 1: 50000 . At present there are only 6 geological maps available at a scale of 1:100 000. In the El Salvador-Guatemala and the El Salvador-Honduras cross-border areas there is considerable necessity to start environmental studies oriented towards the mapping of volcanic risk and the evaluation of the vulnerability of the major cities, settlements, and other densely populated areas.

Different organizations from Germany, Switzerland, Japan, and the Czech Republic are providing international assistance in seismic microzonation, mitigation and mapping of geohazards in some Central American countries (e.g. the Atlas of Geohazards of Central America), and the development of GIS databases (e.g. in Nicaragua, and El Salvador).

In the course of the Workshop there was considerable networking among specialists from Nicaragua, Panama, Costa Rica, Honduras, El Salvador, and other Central America countries and it was agreed to continue this communication via the internet. The Workshop agreed that another meeting to further the study of the relationship between the use of geothermal energy and seismicity, would be held in Costa Rica in 2006.

During the final discussions the importance of the outreach campaign was emphasized, and it was agreed that a number of educational and informational Workshops about vulcanology will be held for governmental organisations and schools.

It was also agreed to exchange information on planned and ongoing activities in cross-border areas using the website of the IUGS-GEM Working Group on International Borders-Geoenvironmental Concerns (http://www.lgt.lt/iborders/).

The Workshop could not have been held without the involvement of the organizations and institutions of the IUGS/IGSV project GeoCrossBorders. Cordial thanks are expressed to the local specialists for the organization and guidance of the field trip. Thanks should also be directed to the Nicaraguan Geosciences Institute (INETER). The common efforts of all the above-mentioned organizations and specialists produced a very successful event in Managua. Moreover, the Workshop was held in a very attractive area, both scientifically and naturally, of volcanoes, calderas, maars, fumaroles, and hot spring fields, with wonderful nature and, what is the most important, people.

\section{Prof. Marek Graniczny}

Polish Geological Institute

4 Rakowiecka Street

00-975 Warsaw

Poland

Dr Jonas Satkunas, Dr Jurga Lazauskiene

Geological Survey of Lithuania

S.Konarskio 35

LT-2600 Vilnius

Lithuania

\section{Dr Jiri Sebesta}

Czech Geological Survey

Klarov 3

11821 Praha 1

Prague

Czech Republic

\title{
CALL FOR PAPERS
}

Episodes is the quarterly science and news journal of the International Union of Geological Sciences (IUGS). It focuses on the publication of results of scientific research and other information addressing issues of interest to the global earth-science community. Special emphasis is given to topics involving geological aspects of population growth and economic development and their resulting impacts on or implications for society. As the principal publication of the IUGS, Episodes also carries information about IUGS scientific programs and activities to the extent necessary to communicate effectively with the worldwide IUGS constituency.

Contributions of the following types of manuscripts are here solicited:

- review papers

- scientific articles

- conference reports

- news and views

- letters to editor

- book reviews

- information on training courses (especially those geared to participants from developing countries)

- noteworthy new publications, including national or regional geologic maps

Episodes also invites photos or other images for the front cover. Photos must be of high technical quality and tell an interesting geological story. A color transparency and one color print (at least $9 \mathrm{~cm} \times 12.6 \mathrm{~cm}$ ) are required for submission, which should be supplemented with a short explanatory paragraph (no more than 100 words).

Please address all contributions to:

\author{
The Editor \\ Episodes \\ P. O. Box 823, 26 Baiwanzhuang Road \\ 100037 Beijing, CHINA \\ Tel: +86-10-68320827, +86-10-68329084 \\ Fax: +86-10-68328928 \\ E-mail: episodes88@yahoo.com
}

